\title{
PROPERTIES AND COMPOSITION OF CARCASS OF DOMESTIC SPOTTED YOUNG CATTLE OF TWO PRE- SLAUGHTER WEIGHTS
}

\author{
M. Petričević ${ }^{1}$, N. Stanišić ${ }^{1}$, Lj. Sretenović ${ }^{1}$, M. M. Petrović ${ }^{1}$, S. Stajić ${ }^{2}$, \\ D. Nikšić ${ }^{1}$ \\ ${ }^{1}$ Institute for Animal Husbandry, Autoput 16, 11080, Belgrade-Zemun, Republic of Serbia \\ ${ }^{2}$ Faculty of Agriculture, Nemanjina 6, 11080, Belgrade-Zemun, Republic of Serbia \\ Corresponding author: majanovakovic@live.com \\ Original scientific paper
}

Abstract: Objective of this research was to determine the slaughter properties and carcass composition of carcass sides derived from young cattle of Domestic Spotted breed, of pre-slaughter weights of 500 (group A) and $600 \mathrm{~kg}$ (group B). Heavier cattle had higher share of kidney fat in carcass, whereas the share of offals showed no significant differences. Statistically significant difference was registered only in share of toungue $(\mathrm{P}<0.05)$, that was higher in cattle of group A. Share of extra/premium (tenderloin), I category (round) and II category (loin, back, shoulder) showed no significant differences between groups of cattle. Statistically significant difference $(\mathrm{P}<0.05)$ was established in the share of III category carcass parts. Share of forearm and chest was significantly higher in lighter cattle $(3.55 \%$ and $7.95 \%)$ compared to heavier animals $(2.89 \%$ and $6.33 \%)$, whereas the share of subshoulder was considerably lower in group A $(6.89 \%)$ compared to cattle of group B $(9.73 \%)$. Data obtained by dissection of main carcass side parts differed significantly in regard to the share of muscle tissue in round and belly, that was significantly higher in cattle of group $\mathrm{A}(\mathrm{P}<0.05)$. Share of fat tissue (subcutaneous and intermuscular) was higher in cattle of group B in almost all carcass side parts, however, statistically significant difference between groups was determined only in round, back, neck and subshoulder. Also, share of bones in chest differed statistically significantly $(\mathrm{P}<0.05)$ and it was higher in group A $(20.09 \%)$ compared to cattle of group B (15.52\%). of tissue

Key words: Domestic Spotted breed, slaughter live weight, carcass, share

\section{Introduction}

In Serbia, production of beef is based on Domestic spotted breed, which is breed of combined production traits. Production of beef since 2001 has been in 
slight increase, but it is still unsatisfactory in regard to number of heads, as well as productivity (Aleksić et al., 2007). Beef is on the third place in regard to consumer preference and consumption (21\%), after pork (40\%) and poultry $(31 \%)$, which is adequate to structure of consumption in countries with low total meat consumption (below $50 \mathrm{~kg}$ per capita) in relation to countries with meat consumption of over $100 \mathrm{~kg}$ (SAD, Australia, Canada etc.) where beef has the highest share in the structure of consumption (Ostojić et al., 2005).

Share of tissues, primarily meat, in retail cuts defines thier quality, value and demand on the market. Beef producers are faced with the task of producing economically the kind of cattle that yield a high percent of high-priced, tender, flavourful, juicy retail cuts, but that have only minimum amounts of waste fat trim (Guenther et al., 1965).

Data on content of tissues in main carcass parts that are available in the literature mainly relate to composition of individual anatomical regions/parts of carcass, with high variations depending on the method of cutting of carcass sides, heterogeneity of the material used in the study (bree, sex, age, fattening level, etc.). In that regard, objective of this research was to determine slaughter properties and composition of carcass sides of Domestic Spotted cattle, of average pre-slaughter weights of 500 and $600 \mathrm{~kg}$.

\section{Materials and Methods}

Trial was carried out on experimental farm, slaughterhouse and laboratory of the Institute for Animal Husbandry, Belgrade-Zemun, Serbia, on 18 young cattle of Domestic Spotted breed. First group of 9 cattle (A) was slaughtered after reacing an average weight of $500 \mathrm{~kg}$, and the second group (B) wight of $600 \mathrm{~kg}$. During the fattening period the rearing system was free, and food consisted of concentrated feeds, hay and corn grain silage. One day prior to slaughtering animals were deprived food, but had free access to water. Prior to slaughtering, which was carried out according to standard commercial procedures, animals were weighed. After removing the skin and head, front and rear rounds and eviseration, carcasses were placed in cold storage at temperature of $4^{0} \mathrm{C}$ for next 24 hours. One hour after slaughter and treatment, mass of warm carcass, mass of offals (heart, lungs, liver, kidenys, spleen and tongue) were taken, also of head, tail and kidney fat.

After chilling, the carcasses were measured and split along the vertebral column in two halves, and the left side was used for all measurements. The left side of each carcass was devided into twelve anatomical regions: round, tenderloin, loin part, shoulder, neck, back, chest, subshoulder, ribs, belly, forearm, and foreround, using a standard technique. All carcass parts were separated into dissectible fat (subcutaneous and intermuscular), muscle and bone tissue. 
In order to determine the effect of slaughter weight on carcass characteristics, a single-factor analysis of variance was performed using Statistica 7 software (StatSoft, USA). If the effect of slaughter weight was found significant, Tukey's test was used to evaluate the significance of difference.

\section{Results and Discussion}

In Table 1, slaughter parameters and shares of slaughtering accompanying products and offals are presented. Dressing percentages of warm and cold carcasses were slightly higher in cattle of group B, but without statistical significance. Stated results for dressing percentage of warm carcass are in accordance with data stated by Waritthitham et al. (2010) and Sanudo et al. (2004). Chilling loss of mass was greater in young cattle of group A $(2.52 \%)$ compared tog roup B $(1.72 \%)$, however, there were no statistically significant differences in this parameter, probably because high variations in the value of chilling loss within groups and high standard deviations.

Aleksic et al. (2009) stated that share of mass of kidney fat in body mass prior to slaughtering was $0.82 \%$ in young cattle with average mass prior to slaughtering of $591.13 \mathrm{~kg}$ and $0.79 \%$ in cattle with average mass prior to slaughtering of $509.00 \mathrm{~kg}$, which is in accordance with data obtained in this trial.

Table 1. Slaughter properties and share of kindey fat, head, tail and offals of young cattle

\begin{tabular}{|l|c|c|c|}
\hline Indicator & A & B & t-test \\
\hline Mass of warm carcass (kg) & $277.00 \pm 11.01$ & $334.58 \pm 15.41$ & $*$ \\
\hline Mass of cold carcass (kg) & $269.93 \pm 15.23$ & $328.77 \pm 14.82$ & $*$ \\
\hline Dressing percentage of warm carcass (\%) & $55.31 \pm 2.10$ & $56.33 \pm 2.39$ & $\mathrm{~ns}$ \\
\hline Dressing percentage of cold carcass (\%) & $55.49 \pm 1.44$ & $57.09 \pm 2.75$ & $\mathrm{~ns}$ \\
\hline Chilling loss (\%) & $2.52 \pm 0.28$ & $1.72 \pm 0.20$ & $\mathrm{~ns}$ \\
\hline Kideny fat (\%) & $0.73 \pm 0.03$ & $0.81 \pm 0.04$ & $*$ \\
\hline Head (\%) & $2.70 \pm 0.22$ & $2.63 \pm 0.19$ & $\mathrm{~ns}$ \\
\hline Tail (\%) & $0.22 \pm 0.04$ & $0.21 \pm 0.05$ & $\mathrm{~ns}$ \\
\hline Offals (\%) & \multicolumn{3}{|l|}{} \\
\hline Kidneys & $0.18 \pm 0.03$ & $0.17 \pm 0.03$ & $\mathrm{~ns}$ \\
\hline Liver & $1.12 \pm 0.11$ & $1.09 \pm 0.10$ & $\mathrm{~ns}$ \\
\hline Lungs & $0.76 \pm 0.08$ & $0.77 \pm 0.09$ & $\mathrm{~ns}$ \\
\hline Heart & $0.37 \pm 0.02$ & $0.32 \pm 0.04$ & $\mathrm{~ns}$ \\
\hline Spleen & $0.19 \pm 0.01$ & $0.19 \pm 0.03$ & $\mathrm{~ns}$ \\
\hline Tongue & $0.35 \pm 0.02$ & $0.28 \pm 0.01$ & $*$ \\
\hline
\end{tabular}

ns - not significant

* significant at the level of $(\mathrm{P}<0.05)$ 
Share of offals showed no significant differences between groups of cattle (Table 1). Statistically significant difference was established only in share of tongue $(\mathrm{P}<0.05)$, that wa shigher in young cattle of group A. Data are in accordance with results obtained by Aleksić et al. (2009) for young cattle of Domestic Simmental breed.

Increasing slaughter weight from 500 up to $600 \mathrm{~kg}$ generally increased body size and weight, carcass size and weight, loin eye area and percentage of commercial prime cuts (Waritthitham et al., 2010). Share of premium cuts (tender loin), I category (round) and II category (loin, shoulder, back) showed no significant differences between groups of cattle (Table 2).

As presented in Table 2, statistically significant difference $(\mathrm{P}<0.05)$ was established in share of forearm, chest and subshoulder. Share of forearm and chest was significantly higher in lighter $(3.55 \%$ and $7.95 \%)$ cattle compared to heavier $(2.89 \%$ and $6.33 \%)$. Share of subshoulder was considerably lower in cattle of group A (6.89\%) compared to group B (9.73\%).

According to results obtained by Aleksić et al. (2009), increasing of body mass prior to slaughter of average 509 to $590 \mathrm{~kg}$, statistically significantly $(\mathrm{P}<0.05)$ increases the share of round/round from $28,39 \%$ to $29,86 \%$. Share of round, in this trial, was slightly higher in heavier cattle, however, difference was not statistically significant (Table 2).

Table 2. Shares of main carcass side parts

\begin{tabular}{|l|c|c|c|}
\hline Carcass side parts (\%) & A & B & t-test \\
\hline Tender loin & $1.77 \pm 0.11$ & $1.85 \pm 0.12$ & $\mathrm{~ns}$ \\
\hline Round & $28.07 \pm 1.46$ & $29.68 \pm 1.37$ & $\mathrm{~ns}$ \\
\hline Parts of II category & \multicolumn{3}{|c|}{} \\
\hline Loin & $4.73 \pm 0.32$ & $4.72 \pm 0.27$ & $\mathrm{~ns}$ \\
\hline Back & $5.37 \pm 0.41$ & $5.09 \pm 0.56$ & $\mathrm{~ns}$ \\
\hline Shoulder & $13.25 \pm 0.70$ & $13.04 \pm 0.52$ & $\mathrm{~ns}$ \\
\hline Total & $23.63 \pm 0.98$ & $23.21 \pm 1.17$ & $\mathrm{~ns}$ \\
\hline Parts of III category & \multicolumn{3}{|l|}{} \\
\hline Round & $4.17 \pm 0.38$ & $4.03 \pm 0.32$ & $\mathrm{~ns}$ \\
\hline Foreshank & $3.55 \pm 0.11$ & $2.89 \pm 0.10$ & $*$ \\
\hline Neck & $9.87 \pm 0.75$ & $9.74 \pm 0.63$ & $\mathrm{~ns}$ \\
\hline Breast & $7.95 \pm 0.38$ & $6.33 \pm 0.24$ & $*$ \\
\hline Subshoulder & $6.89 \pm 0.27$ & $9.73 \pm 0.49$ & $\mathrm{~ns}$ \\
\hline Ribs & $7.29 \pm 0.59$ & $7.11 \pm 1.06$ & $\mathrm{~ns}$ \\
\hline Belly & $5.53 \pm 1.01$ & $5.79 \pm 0.75$ & $\mathrm{~ns}$ \\
\hline Total & $46.20 \pm 1.22$ & $45.57 \pm 2.13$ & \\
\hline
\end{tabular}

ns - not significant

$*$ significant at the level of $(\mathrm{P}<0.05)$ 
Weight and size of a carcass has a major influence not only on the quantity of the various tissues but also on the size of muscle exposed to cutting and the individual joints prepared from it (Kampster, 1992).

Pdata obtained by dissection of main carcass parts are presented in Table 3. Shares of muscle tissue in round and belly were considerably higher in cattle of group A $(\mathrm{P}<0.05)$. Share of chest muscle tissue was also higher in lighter animals (66.26\%) compared to heavier cattle $(62.27 \%)$, however, this difference was not statistically significant. Waritthitham et al. (2010) state that share of muscle tissue decreasesm and share of fat tissue increases in young cattle of pre-slaughter weight of $600 \mathrm{~kg}$ compared to those slaughtered at weight of $500 \mathrm{~kg}$. Similar results were obtained by Sanudo et al. (2004).

In the study of the composition of beef carcasses obtained from cattle of average pre-slaughter weight of $597 \mathrm{~kg}$, Aleksić et al. (2007) state the share of muscle tissue in round of approx. 86\%, in II category cracass parts (loin, back, shoulder) approx. 78\%, and in III category parts (neck, subshoulder, forearm, chest, ribs, foreshank) approx. $73 \%$.

Share of fat tissue (subcutaneous and intermuscular) was higher in cattle of group B in almost all carcass side parts, however, statistically significant difference between groups was recorded only for round, back, neck and subshoulder (Table 3). In case of loin, shoulder, chest, ribs and belly, although higher value for the share of fat tissue in cattle of group B was determined, due to great variations of this parameter within group, no statistically signiicant difference was established. Obtained data are not in accordance with conclusion stated by Keane and Allen (2002) that extending the feeding time to raise crossbred cattle up to $600 \mathrm{~kg}$ live weight does not increase the fat tissue proportion.

Share of chest bones showed statistically significant difference $(\mathrm{P}<0.05)$ and it was higher in cattle of group A $(20.09 \%)$ compared to cattle of group B (15.52\%). Sanudo et al. (2004) in their study show share of bones lower than in cattle of pre-slaughter weight of $550 \mathrm{~kg}$, compared to cattle of pre-slaughter weight of $300 \mathrm{~kg}$, which is in accordance with results presented in this study. 
Table 3. Shares of muscle tissue, fat tissue and bones in main carcass side parts

\begin{tabular}{|c|c|c|c|}
\hline Carcass part/tissue (\%) & A & $\mathrm{B}$ & t-test \\
\hline \multicolumn{4}{|l|}{ Round } \\
\hline Meat & $85.37 \pm 3.32$ & $81.52 \pm 2.95$ & $*$ \\
\hline Fat & $2.91 \pm 0.21$ & $5.79 \pm 0.33$ & $*$ \\
\hline Bone & $12.82 \pm 0.89$ & $12.35 \pm 1.12$ & ns \\
\hline \multicolumn{4}{|l|}{ Loin } \\
\hline Meat & $71.99 \pm 3.14$ & $69.28 \pm 5.27$ & ns \\
\hline Fat & $3.93 \pm 1.26$ & $5.06 \pm 2.01$ & $\mathrm{~ns}$ \\
\hline Bone & $23.70 \pm 2.34$ & $23.22 \pm 3.15$ & ns \\
\hline \multicolumn{4}{|l|}{ Back } \\
\hline Meat & $69.30 \pm 2.89$ & $71.71 \pm 5.62$ & ns \\
\hline Fat & $5.45 \pm 0.30$ & $7.63 \pm 0.54$ & * \\
\hline Bone & $21.98 \pm 2.41$ & $19.28 \pm 3.36$ & ns \\
\hline \multicolumn{4}{|l|}{ Shoulder } \\
\hline Meat & $81.88 \pm 2.04$ & $80.58 \pm 4.96$ & ns \\
\hline Fat & $2.11 \pm 1.17$ & $4.02 \pm 1.28$ & ns \\
\hline Bone & $16.0 \pm 1.04$ & $15.52 \pm 1.85$ & ns \\
\hline \multicolumn{4}{|l|}{ Chest } \\
\hline Meat & $66.26 \pm 5.98$ & $62.27 \pm 6.82$ & ns \\
\hline Fat & $13.49 \pm 3.28$ & $19.58 \pm 4.79$ & ns \\
\hline Bone & $20.09 \pm 1.53$ & $15.52 \pm 1.03$ & $*$ \\
\hline \multicolumn{4}{|l|}{ Ribs } \\
\hline Meat & $78.57 \pm 4.83$ & $77.41 \pm 7.86$ & ns \\
\hline Fat & $4.67 \pm 1.34$ & $9.02 \pm 3.16$ & ns \\
\hline Bone & $17.55 \pm 3.55$ & $12.58 \pm 2.35$ & ns \\
\hline \multicolumn{4}{|l|}{ Neck } \\
\hline Meat & $84.21 \pm 4.50$ & $81.23 \pm 6.10$ & ns \\
\hline Fat & $1.22 \pm 0.13$ & $7.74 \pm 0.71$ & $*$ \\
\hline Bone & $13.14 \pm 2.70$ & $11.30 \pm 1.90$ & ns \\
\hline \multicolumn{4}{|l|}{ Subshoulder } \\
\hline Meat & $75.01 \pm 4.20$ & $71.05 \pm 5.85$ & ns \\
\hline Fat & $2.80 \pm 0.23$ & $7.22 \pm 0.68$ & $*$ \\
\hline Bone & $20.01 \pm 2.36$ & $19.59 \pm 4.86$ & ns \\
\hline \multicolumn{4}{|l|}{ Belly } \\
\hline Meat & $80.33 \pm 5.78$ & $74.26 \pm 4.54$ & $*$ \\
\hline Fat & $18.42 \pm 4.12$ & $23.01 \pm 3.66$ & ns \\
\hline Bone & $1.19 \pm 0.26$ & $1.04 \pm 0.22$ & ns \\
\hline \multicolumn{4}{|l|}{ Round } \\
\hline Meat & $45.34 \pm 4.15$ & $43.90 \pm 2.17$ & ns \\
\hline Fat & $1.72 \pm 0.77$ & $3.14 \pm 1.19$ & ns \\
\hline Bone & $51.36 \pm 4.28$ & $51.08 \pm 2.98$ & ns \\
\hline \multicolumn{4}{|l|}{ Foreshank } \\
\hline Meat & $57.23 \pm 4.28$ & $55.26 \pm 3.98$ & ns \\
\hline Fat & $1.36 \pm 0.38$ & $3.05 \pm 0.59$ & ns \\
\hline Bone & $40.92 \pm 4.66$ & $40.22 \pm 2.18$ & ns \\
\hline
\end{tabular}

ns - not significant

* significant at the level of $(\mathrm{P}<0.05)$ 


\title{
Conclusion
}

Based on results presented in this paper it can be concluded that Domestic spotted cattle of pre-slaughter weight of 500 and $600 \mathrm{~kg}$, show no significant differences in slaughter properties and shares of accompanying products of the carcass. Statistically significant difference was established in higher share of kidney fat and fat tissue in main carcass side parts in heavier cattle, whereas the lighter animals had considerably higher share of muscle tissue in round and belly.

\section{Acknowledgment}

Research was financed by the Ministry of Education and Science, Republic of Serbia, project TR-31053.

\section{Osobine i sastav trupa junadi domaće šarene rase različitih težina pred klanje}

\author{
M. Petričević, N. Stanišić, Lj. Sretenović, M. M. Petrović, S. Stajić, D. Nikšić
}

\section{Rezime}

Cilj ovog istraživanja bio je da se utvrde klanične osobine i sastav polutki junadi domaće šarene rase, zaklanih pri dostizanju prosečne težine od 500 (grupa A) i $600 \mathrm{~kg}$ (grupa B). Teža junad su imala veći udeo bubrežnog loja u trupu, dok se udeo iznutrica nije značajno razlikovao. Statistički značajna razlika je pronađena samo u udelu jezika $(\mathrm{P}<0.05)$, koji je bio veći kod junadi grupe A. Udeo delova ekstra (biftek), I kategorije (but) i II kategorije (slabine, leđa, plećka) nisu se značajno razlikovali između grupa junadi. Statistički značajna razlika $(\mathrm{P}<0.05)$ je pronađena u udelu delova III kategorije. Udeo podlaktice i grudi bio je značajno veći kod lakših (3.55\% i 7.95\%) u odnosu na težu junad (2.89\% i 6.33\%), dok je udeo potplećke bio znatno niži kod junadi grupe A $(6.89 \%)$ u odnosu na junad grupe B (9.73\%). Podaci dobijeni disekcijom osnovnih delova polutke su se statistički značajno razlikovali u udelu mišićnog tkiva u butu i potrbušini, koji je bio značajno veći kod junadi grupe $\mathrm{A}(\mathrm{P}<0.05)$. Udeo masnog tkiva (potkožnog $\mathrm{i}$ intermuskularnog) je bio veći kod junadi grupe B kod gotovo svih delova polutke, međutim, statistički značajna razlika između grupa je pronađena samo kod buta, leđa, vrata i potplećke. Takođe, udeo kostiju grudi se statistički značajno razlikovao $(\mathrm{P}<0.05)$ i bio je veći kod junadi grupe A $(20.09 \%)$ u poređenju sa junadima grupe $\mathrm{B}(15.52 \%)$. 


\section{References}

ALEKSIĆ S., JOSIPOVIĆ S., TOMAŠEVIĆ D., MARINKOV G., OSTOJIĆANDRIĆ D. (2007): Udeo tkiva u maloprodajnim delovima junećih trupova. Biotechnology in Animal Husbandry 23, 75-81.

ALEKSIĆ S., PETROVIĆ M.M., PANTELIĆ V., NOVAKOVIĆ Ž., STANIŠIĆ N., NOVAKOVIĆ M. (2009): Investigation of the effect of mass prior to slaughtering on slaughter values of male fattening young cattle of Domestic Simmental breed. Biotechnology in Animal Husbandry, 25, 93-99.

GUENTHER J.J., BUSHMAN D.H., POPE L.S., MORRISON R.D. (1965): The effect of plane of nutrition calves from weaning to slaughter weight, with reference to growth and development of the major carcass tissues in beef. Journal of Animal Science, 24, 1184-1191.

KAMPSTER A.J. (1992): Carcass characteristics and quality. In JARRINGE R., BÉRANGER C. (eds.), World animal science, C5, Beef cattle production. Amsterdam, Elsevier, 131-149.

KEANE M.G., ALLEN P. (2002): A comparison of Friesian-Holstein, Piemontese $\mathrm{x}$ Friesian-Holstein and Romagnola $\mathrm{x}$ Friesian-Holstein steers for beef production and carcass traits. Livestock Production Science, 78, 143-158.

OSTOJIĆ D., BOGDANOVIĆ V., PETROVIĆ M.M., ALEKSIĆ S., MIŠČEVIĆ B., PANTELIĆ V. (2005): Criteria of consumers when purchasing beef in retail stores, A. Consumer attitude towards beef quality preferences and habits in selection of the category of retail meat parts and giblets. Biotechnology in Animal Husbandry, 21, 2, 263-268.

SANUDOA C., MACIEA E.S., OLLETAA J.L., VILLARROEL M., PANEAA B., ALBERT P. (2004): The effects of slaughter weight, breed type and ageing time on beef meat quality using two different texture devices. Meat Science, 66, 925-932. WARITTHITHAM A., LAMBERTZ C., LANGHOLZ H.J., WICKE M., GAULY M. (2010): Assessment of beef production from Brahman $\mathrm{x}$ Thai native and Charolais $\mathrm{x}$ Thai native crossbred bulls slaughtered at different weights. I: Growth performance and carcass quality. Meat Science, 85, 191-195. 